\title{
Jadwal Imunisasi Rekomendasi IDAI
}

\author{
Satgas Imunisasi IDAI
}

D alam mempergunakan bagan jadwal imunisasi IDAI edisi Agustus 1999 untuk keperluan praktek sehari-hari, perlu penjelasan sebagai berikut,

a) Penyusunan jadwal Imunisasi periode Agustus 1999 dibuat dengan memperhatikan range (tenggang) waktu imunisasi yang dianjurkan, dengan maksud agar supaya teman sejawat dapat memberikan waktu yang lebih tepat dan leluasa kepada pasien, kapan imunisasi sebaiknya diberikan sesuai dengan kedatangan/ kebutuhan anak.

b) Jadwal imunisasi menurut Program Pengembangan Imunisasi (PPI) Depkes tetap dapat dipergunakan, bersama jadwal imunisasi IDAI.

c) Jadwal Imunisasi IDAI setiap tahun akan dievaluasi untuk penyempurnaan, berdasarkan pada hasil penelitian mengenai perubahan pola penyakit, kebijakan Depkes/ WHO, dan pengadaan vaksin di Indonesia.

\section{Ketentuan Umum Pemberian Imunisasi \\ Indikasi kontra (contra indication) dan perhatian khusus (precaution)}

Indikasi kontra imunisasi adalah keadaan yang menyebabkan imunisasi tidak boleh diberikan. Perhatian khusus pada imunisasi adalah keadaan yang perlu diperhatikan apakah memungkinkan imunisasi diberikan, dengan cara melakukan pemeriksaan fisik yang teliti, dan memperhitungkan risiko keuntungan dan kerugiannya. Indikasi kontra dan perhatian khusus

Satuan Tugas Imunisasi PP. IDAI

Alamat korespondensi:

Satgas Imunisasi PP. IDAI

Gedung IDAI Bagian Ilmu Kesehatan Anak FKUI-RSCM

Jl. Salemba No. 6, Jakarta 10430, Indonesia.

Telpon: (021) 391 4126. Fax.: (021) 391 4126,

e-mail: saripediatri@idai.com dapat berlaku untuk semua vaksin atau hanya untuk vaksin tertentu. Pada dasarnya indikasi kontra dan perhatian khusus terdiri dari 2 aspek yaitu, (1) reaksi anafilaksis terhadap vaksin atau komponen vaksin dan (2) indikasi kontra terhadap imunisasi untuk penyakit akut yang berat dengan atau tanpa demam.

\section{Cara dan tempat pemberian vaksin}

Vaksin dapat diberikan secara subkutan, intramuskular, intrakutan (intradermal), dan per-oral sesuai dengan petunjuk yang tertera dalam kemasan. Cara pemberian vaksin selalu tertera pada label vaksin, maka harus dibaca dengan baik. Vaksin harus diberikan pada tempat yang dapat memberikan respons imun optimal dan memberikan kerusakan minimal terhadap jaringan sekitar, pembuluh darah maupun persarafan.

Suntikan subkutan tidak mengganggu sistem neurovaskular, biasanya diberikan untuk vaksin hidup dan vaksin yang menghasilkan imunogenisitas yang tinggi apabila diberikan secara subkutan. Vaksin yang seharusnya diberikan intramuskular (misalnya Hepatitis B) akan menurun imunogenisitasnya apablia diberikan subkutan.

Suntikan subkutan pada bayi diberikan pada paha atas bagian anterolateral atau daerah deltoid untuk anak besar. Jarum yang dipergunakan berukuran 5/8-3/4 inci yaitu jarum ukuran 23-25. Kulit dan jaringan di bawahnya dicubit tebal perlahan dengan mempergunakan jempol dan jari telunjuk sehingga terangkat dari otot, kemudian jarum ditusukkan pada lipatan kulit tersebut dengan kemiringan kira-kira 45 derajat.

Suntikan intramuskular secara umum direkomendasikan pada vaksin yang berisi ajuvan, apabila diberikan secara subkutan atau intradermal dapat menyebabkan iritasi pada kulit setempat, menimbulkan indurasi, kulit menjadi pucat, reaksi inflamasi, dan pembentukan granuloma, Pemilihan tempat dan ukuran jarum harus mempertimbangkan volume vaksin, tebal jaringan subkutan, dan tebal otot. M.quadricep pada anterolateral tungkai atas dan M.deltoideus merupakan pilihan untuk suntikan intramuskular, dengan 
mempergunakan jarum nomor 22-25. Menurut pedoman WHO, pada suntikan intramuskular, jarum harus masuk $5 / 8$ inci atau $16 \mathrm{~mm}$ sedangkan FDA menganjurkan kedalaman 7/8-1 inci atau 22-25 mm.

Suntikan intradermal diberikan pada BCG dan kadang-kadang pada vaksin rabies dan tifoid, pada lengan atas atau daerah volar. Ukuran jarum 3/8-3/4 inci atau jarum nomor 25-27. Untuk vaksin oral, apabila dalam 10 menit anak muntah sebaiknya pemberian vaksin diulang; tetapi bila kemudian muntah lagi ulangan diberikan pada keesokan harinya.

\section{Bayi lahir kurang bulan}

Pada dasarnya jadwal imunisasi bayi kurang bulan sama dengan bayi cukup bulan. Hal-hal yang perlu diperhatikan pada bayi kurang bulan adalah (1) titer imunitas pasif melalui transmisi maternal lebih rendah daripada bayi cukup bulan; (2) apabila berat badan bayi sangat kecil (<1000 gram), imunisasi diberikan setelah berat badan bayi mencapai 2000 gram atau umur bayi 2 bulan; (3) untuk imunisasi Hepatitis B1 diberikan pada umur 2 bulan atau lebih, kecuali apabila diketahui ibu mempunyai titer HBsAg positif; dan (4) apabila bayi masih dirawat setelah umur 2 bulan, vaksin polio sebaiknya diberikan secara suntikan (IPV, in active polio vaccine) sehingga tidak menyebarkan virus polio melalui tinja bayi.

\section{Pasien imunokompromais}

Keadaan imunokompromais dapat terjadi sebagai akibat penyakit dasar atau akibat pengobatan. Indikasi kontra pasien imu-nokompromais, sebagian besar disebabkan oleh vaksin hidup. Imunisasi tetap dapat diberikan pada pengobatan kortikosteroid dosis kecil dan dalam waktu pendek. Perhatian khusus diperuntukkan pada pasien dengan pengobatan kortikosteroid sistemik dengan dosis $2 \mathrm{mg} / \mathrm{kg}$ berat badan/ hari atau prednison $20 \mathrm{mg}$ / hari selama 14 hari, maka imunisasi dapat diberikan setelah pengobatan dihentikan minimal 1 bulan.

\section{BCG}

- Imunisasi BCG diberikan pada umur sebelum 2 bulan. Pada dasarnya, untuk mencapai cakupan yang lebih luas, pedoman Depkes perihal imunisasi
BCG pada umur antara 0-12 bulan, tetap disetujui.

- Dosis untuk bayi < 1 tahun adalah 0,05 $\mathrm{ml}$ dan anak $0,10 \mathrm{ml}$, diberikan intrakutan di daerah insersio $M$. deltoideus kanan.

- BCG ulangan tidak dianjurkan oleh karena manfaatnya diragukan mengingat (1) efektivitas perlindungan hanya 40\%, (2) 70\% kasus TBC berat (meningitis) ternyata mempunyai parut BCG, dan (3) kasus dewasa dengan BTA (bakteri tahan asam) positif di Indonesia cukup tinggi (25-36\%) walaupun mereka telah mendapat BCG pada masa kanak-kanak.

- BCG tidak diberikan pada pasien imunokompromais (leukemia, dalam pengobatan steroid jangka panjang, infeksi HIV, dan lain lain).

- Apabila BCG diberikan pada umur >3bulan, sebaiknya dilakukan uji tuberkulin terlebih dahulu.

\section{Hepatitis B}

- Imunisasi hepatitis B diberikan sedini mungkin setelah lahir, mengingat paling tidak 3,9\% ibu hamil merupakan pengidap hepatitis dengan risiko transmisi maternal kurang lebih sebesar 45\%.

- Pemberian imunisasi hepatitis B harus berdasarkan status HBsAg ibu pada saat melahirkan. Jadwal pemberian berdasarkan status HBsAg ibu adalah sebagai berikut:

- Bayi lahir dari ibu dengan status HbsAg yang tidak diketahui. Diberikan vaksin rekombinan (HB Vax-II $5 \mu \mathrm{g}$ atau Engerix B $10 \mu \mathrm{g}$ ) atau vaksin plasma derived $10 \mathrm{mg}$, secara intramuskular, dalam waktu 12 jam setelah lahir. Dosis kedua diberikan umur 1-2 bulan dan dosis ketiga umur 6 bulan. Apabila pada pemeriksaan selanjutnya diketahui ibu HbsAg-nya positif, segera berikan $0,5 \mathrm{ml}$ HBIG (sebelum 1 minggu).

- Bayi lahir dari ibu HBsAg positif. Dalam waktu 12 jam setelah lahir, secara bersamaan, diberikan 0,5 ml HBIG dan vaksin rekombinan (HB Vax-II $5 \mathrm{mg}$ atau Engerix B $10 \mathrm{mg}$ ), intramuskular di sisi tubuh yang berlainan. Dosis kedua diberikan 1-2 bulan sesudahnya dan dosis ketiga diberikan pada usia 6 bulan.

- Bayi lahir dari ibu dengan HBsAg negatif. Diberikan vaksin rekombinan (HB Vax-II dengan dosis minimal 2,5 $\mu \mathrm{g}(0,25 \mathrm{ml})$ atau Engerix B $10 \mu \mathrm{g}(0,5 \mathrm{ml})$, vaksin plasma derived dengan dosis $10 \mu \mathrm{g}(0,5 \mathrm{ml})$ secara intra- 
muskular, pada saat lahir sampai usia 2 bulan. Dosis kedua diberikan 1-2 bulan kemudian dan dosis ketiga diberikan 6 bulan setelah imunisasi pertama.

- Ulangan imunisasi hepatitis B (HepB4) dapat dipertimbangkan pada umur 10-12 tahun.

- Idealnya dilakukan pemeriksaan anti BHs (paling cepat) 1 bulan pasca imunisasi hepatitis B ketiga.

- Telah dilakukan suatu penelitian multisenter di Thailand dan Taiwan terhadap anak dari ibu pengidap hepatitis $B$, yang telah memperoleh imunisasi dasar 3x pada masa bayi. Pada umur 5 tahun, sejumlah 90,7\% diantaranya masih memiliki titer antibodi anti HBs yang protektif (titer anti $\mathrm{HBs}>10 \mu \mathrm{g} / \mathrm{ml}$ ). Mengingat pola epidemiologi hepatitis B di Indonesia mirip dengan pola epidemiologi negara tersebut, maka dapat disimpulkan bahwa imunisasi ulang (booster) pada usia 5 tahun, tidak diperlukan. Idealnya, pada usia ini dilakukan pemeriksaan anti HBs.

- Apabila sampai dengan usia 5 tahun anak belum pernah memperoleh imunisasi hepatitis $\mathrm{B}$, maka diberikan secepatnya (catch-up vaccination).

\section{DPT}

- Imunisasi DPT dasar diberikan 3 kali sejak umur 2 bulan dengan interval 4-6 minggu, DPT 1 diberikan pada umur 2-4 bulan, DPT 2 pada umur 3-5 bulan dan DPT 3 pada umur 4-6 bulan. Ulangan selanjutnya (DPT 4) diberikan satu tahun setelah DPT 3 yaitu pada umur 18-24 bulan dan DPT 5 pada saat masuk sekolah umur 5-7 tahun.

- Sejak tahun 1998, DT 5 dapat diberikan pada kegiatan imunisasi di sekolah dasar (BIAS). Ulangan DT 6 diberikan pada 12 tahun, mengingat masih dijumpai kasus difteria pada umur $>10$ tahun.

- Sebaiknya ulangan DT 6 pada umur 12 tahun diberikan $d T$ (adult dose), tetapi di Indonesia dT belum ada di pasaran.

- Dosis DPT/ DT adalah 0,5 ml, intramuskular, baik untuk imunisasi dasar maupun ulangan.

\section{Tetanus}

- Upaya Departemen Kesehatan melaksanakan Program Eliminasi Tetanus Neonatorum (ETN) melalui imunisasi DPT, DT, atau TT dilaksanakan berdasarkan perkiraan lama waktu perlindungan sebagai berikut:

- Imunisasi DPT pada bayi 3 kali (3 dosis) akan memberikan imunitas 1-3 tahun. Dari 3 dosis toksoid tetanus pada bayi tersebut setara dengan 2 dosis toksoid pada anak yang lebih besar atau dewasa.

- Ulangan DPT pada umur 18-24 bulan (DPT 4) akan memperpanjang imunitas 5 tahun yaitu sampai dengan umur 6-7 tahun, pada umur dewasa dihitung setara 3 dosis toksoid.

- Dosis toksoid tetanus kelima (DPT/ DT 5) bila diberikan pada usia masuk sekolah, akan memperpanjang imunitas 10 tahun lagi yaitu pada sampai umur 17-18 tahun; pada umur dewasa dihitung setara 4 dosis toksoid.

- Dosis toksoid tetanus tambahan yang diberikan pada tahun berikutnya di sekolah (DT 6 atau dT) akan memperpanjang imunitas 20 tahun lagi; pada umur dewasa dihitung setara 5 dosis toksoid.

- Jadi Program Imunisasi merekomendasikan TT $5 \mathrm{x}$ untuk memberikan perlindungan seumur hidup dan pada wanita usia subur (WUS) untuk memberikan perlindungan terhadap bayi yang dilahirkan dari tetanus neonatorum.

- Dosis TT 0,5 ml diberikan secara intramuskular.

- Upaya mencapai target Eliminasi Tetanus Neonatorum dengan target sasaran TT $5 x$ selain pada sasaran bayi, juga pada anak sekolah melalui kegiatan Bulan Imunisasi Anak Sekolah (BIAS). Program BIAS dilaksnakan secara bertahap dengan jadwal seperti tertera pada Tabel 1 .

\section{Polio}

- Untuk imunisasi dasar (polio 2, 3, 4), vaksin diberikan 2 tetes per-oral, dengan interval tidak kurang dari 4 minggu. Mengingat Indonesia merupakan daerah endemik polio, sesuai pedoman PPI untuk men-dapatkan cakupan imunisasi yang lebih tinggi, diperlukan tambahan imunisasi polio yang diberikan segera setelah lahir (pada kunjungan I).

- Perlu mendapat perhatian pada pemberian polio 1 saat bayi masih berada di rumah bersalin/ rumah sakit, dianjurkan vaksin polio diberikan pada saat bayi akan dipulangkan agar tidak mencemari bayi lain mengingat virus polio hidup dapat diekskresi melalui tinja. 
- Imunisasi polio ulangan diberikan satu tahun sejak imunisasi polio 4, selanjutnya saat masuk sekolah (5-6 tahun).

\section{Campak}

- Vaksin campak dianjurkan diberikan dalam satu dosis $0,5 \mathrm{ml}$ secara sub-kutan dalam, pada umur 9 bulan.

- Hasil penelitian terhadap titer antibodi campak pada anak sekolah kelompok usia 10-12 tahun didapat hanya $50 \%$ diantaranya masih mempunyai antibodi campak di atas ambang pencegahan, sedangkan 28,3\% diantara kelompok usia $5-7$ tahun pernah menderita campak walaupun sudah diimunisasi saat bayi. Berdasarkan penelitian tersebut dianjurkan pemberian imunisasi campak ulangan pada saat masuk sekolah dasar (5-6 tahun), guna mempertinggi serokonversi (lihat program BIAS, tabel 1).

\section{MMR}

- Vaksin MMR diberikan pada umur 15-18 bulan dengan dosis satu kali $0,5 \mathrm{ml}$, secara subkutan.

- Vaksin MMR yang beredar di pasaran ialah MMRII $[M S D]^{\circledR}$ dan Trimovax [Pasteur Merieux $]^{\circledR}$

- MMR diberikan minimal 1 bulan sebelum atau setelah penyuntikan imunisasi lain.

- Apabila seorang anak telah mendapat imunisasi MMR pada umur 12-18 bulan, imunisasi campak 2 pada umur 5-6 tahun tidak perlu diberikan.

- Ulangan diberikan pada umur 10-12 tahun atau 12-18 tahun.

\section{Hib (H.influenzae tipe b)}

- Vaksin conjungate H.influenzae tipe b ialah Act HIB [Pasteur Merieux $]^{\circledR}$ diberikan pada umur 2, 4, dan 6 bulan. Bila dipergunakan vaksin $P R P$-outer membrane protein complex (PRP-OMPC) yaitu Pedvax Hib, $[M S D]{ }^{\circledR}$ diberikan pada umur 2 dan 4 bulan, dosis ketiga (6 bulan) tidak diperlukan.

- Ulangan vaksin Hib diberikan pada umur 18 bulan.

- Apabila anak datang pada umur 1-5 tahun, Hib hanya diberikan 1 kali.

- Satu dosis vaksin Hib berisi $0,5 \mathrm{ml}$, diberikan secara intramuskular.

\section{Demam tifoid}

- Di Indonesia tersedia 2 jenis vaksin yaitu vaksin suntikan (polisakarida) dan oral. Vaksin capsular Vi polysaccharide yaitu Typhim Vi [Pasteur Merieux ${ }^{\circledR}$ diberikan pada umur $>2$ tahun, ulangan dilakukan setiap 3 tahun.

- Tifoid oral Ty21a yaitu Vivotif $[\text { Berna }]^{\circledR}$ diberikan pada umur $>6$ tahun, dikemas dalam 3 dosis dengan interval selang sehari (hari 1,3, dan 5). Imunisasi ulangan dilakukan setiap 3-5 tahun.

\section{Hepatitis A}

- Vaksin hepatitis A diberikan pada daerah yang kurang terpajan (under exposure), pada umur $>2$ tahun. Imunisasi dasar Hepatitis A yang telah beredar ialah Havrix [Smith Kline Beecham ${ }^{\circledR}$ dosis pemberian sebagai berikut, Dosis 360 U diberikan

Tabel 1. Program BIAS di Indonesia tahun 1998-2001

\begin{tabular}{ccccccc}
\hline \multirow{2}{*}{ SD } & Tahun & \multicolumn{2}{c}{ Tahun 1999 } & \multicolumn{2}{c}{ Tahun 2000 } & Tahun 2001 \\
\cline { 3 - 5 } Kelas & 1998 & rutin & khusus & rutin & khusus & dst \\
\hline & & & & & \\
1 & DT & DT & & DT & Campak & DT + Campak \\
2 & TT & TT & & TT & Campak & TT \\
3 & TT & TT & Polio & TT & Campak + Polio & TT \\
4 & TT & TT & Polio & TT & Campak + Polio & \\
5 & TT & TT & Polio & TT & Campak + Polio & \\
6 & TT & TT & Polio & TT & Campak + Polio & \\
\hline
\end{tabular}


Sari Pediatri, Vol. 2, No. 1, Juni 2000

$3 \mathrm{x}$ dengan interval 4 minggu antara suntikan I dan II. Untuk mendapatkan perlindungan jangka panjang (10 tahun) dengan nilai ambang pencegahan $>20 \mathrm{mlU} / \mathrm{ml}$, dosis ketiga diberikan 6 bulan setelah suntikan pertama. Apabila dipergunakan dosis 720 $\mathrm{U}$, imunisasi cukup diberikan dua kali dengan interval 6 bulan.

- Suntikan diberikan secara intramuskular di daerah deltoid.

\section{Varisela}

Efektifitas vaksin varisela tidak diragukan lagi, tetapi karena cakupan imunisasi belum tinggi oleh karena harga belum terjangkau bagi sebagian masyarakat maka imunisasi rutin belum dapat terlaksana. Pada pemberian vaksin varisela pada anak kecil dapat mengubah epidemiologi penyakit dari masa anak ke dewasa (pubertas), sebagai akibatnya angka kejadian varisela orang dewasa akan meningkat dibandingkan anak; sedangkan dampak penyakit pada orang dewasa lebih berat apalagi bila terjadi pada masa kehamilan dapat mengakibatkan bayi menderita sindrom varisela kongenital dengan angka kematian yang tinggi. Oleh karena itu untuk menghindarkan perubahan epidemiologi penyakit tersebut, pada saat ini imunisasi varisela yaitu Varillix ${ }^{\circledR}$ [Smith Kline Beecham ${ }^{\circledR}$ direkomendasikan pada umur 10-12 tahun yang belum terpajan, dengan dosis $0,5 \mathrm{ml}$, subkutan, satu kali. Apabila diberikan pada umur $>13$ tahun maka imunisasi diberikan 2 kali dengan jarak 4-8 minggu.
Di lain pihak, atas permintaan orang tua imunisasi varisela dapat diberikan kapan saja setelah anak berusia 1 tahun. Imunisasi ulangan sampai saat ini belum dianjurkan.

\section{Daftar Pustaka}

1. Plotkins SA, Orenstein WA., penyunting. Vaccines, edisi ketiga. Philadelphia, Tokyo; Saunders, 1999:

2. Report of the Committee on Infectious Diseases. American Academy of Pediatrics. Illinois; Amerika Serikat, 1997.

3. National Health and Medical Research Council. National Immunisation Program: The Australian Immunisation Handbook. Edisi ke-6. Commonwealth of Australia, 1997.

4. Startton KR., Howe CJ, Johnston RB, penyunting. Adverse events associated with childhood vaccines. Division of Promotion and Disease Prevention, Institute of Medicine. Washington DC; National Academy Press, 1994.

5. World Health Organization Children Vaccine Initiative. Strategic Planning. Managing opportunity of change a vision of vaccination for the 21 th century. Geneva: Children's Vaccine Initiative-WHO, 1997.

6. Petunjuk Teknis Bulan Imunisasi Anak Sekolah "BIAS", Bagi Pengelola Program. Dijen PPM\&PLP, Subdit Epidemiologi \& Imunisasi, Departemen Kesehatan;Tim Pembina UKS Pusat, 1997.

7. Kassianos GC. Immunization. Edisi ketiga. London: Blackwell Science, 1996.

8. Cutt FT. Vaccination \& World Health. Dalam: Cutt FT, Smith PG., penyunting. Chichester, UK: London School of Hygiene \& Tropical Medicine, John Wiley \& sons, 1994. 